\title{
Fire in de Cane: METAPHORS OF INDO TRINIDADIAN IDENTITY IN RAMABAI ESPINET'S The Swinging Bridge
}

\section{Rosanne Kanhai Western Washington University}

\author{
kaisebani kaisebani/ \\ mi Nana and mi Nanee was flying in a plane/ \\ the plane catch a fire/ they fall inside the cane \\ (Sundar Popo)
}

The evolution of identity is on-going, yet to articulate identity is the self analysis of a people's understanding of who they are at a particular time. Perhaps in more stable societies, identity has not been a preoccupation, not the "stuff" of literature and other types of art. However, for us, in the western hemisphere, where indigenous populations have been brutally decimated and room made for more brutality in the uprootment, transportation and relocation of peoples from different parts of the globe, we find it a crucial to pause and understand who we are as we connect with each other. In the Caribbean, the articulations of identity are also placed within the geographic structure of an archipelago of islands. 


\section{Ethnic Studies Review Volume 31}

Physically each island is surrounded by the mighty Atlantic, yet each is one step away the other. Historically and psychologically, the Caribbean populations are also one step away from their ancestral cultures, from the colonial cultures, and from the dominant culture of North America. A "swinging bridge" is an apt metaphor to explore the Caribbean history and reality of flux yet rooted-ness, of connectedness yet separation.

This paper is particularly concerned with Caribbeans of Indian descent. To mention Indians in the Caribbean is to come face to face with the colonial arrogance toward both the people of India and original inhabitants who, ironically were renamed "Indians." In European racialized thinking there was no distinction between these two vastly different populations and civilizations. They were simply "barbaric" and could be compelled to contribute to the "progress" and "welfare" of the white "master" race. It is not necessary for me to refer to the many ways in which Europeans articulated and enacted their entitlement to world hegemony and supremacy. More important is to pay respects to the first inhabitants of the region - the Taino tribes who canoo-ed up and down those warm waters. The largest tribe-the Caribs - gave their name to that "elliptical basin" (to use Derek Walcott's poetic phrase) (387) that continues to be criss-crossed. Jacqui Alexander makes central to her thinking "the tidal currents of the Middle Passage" (6) as she tells the spiritual history of Africans who were enslaved and brought across the Atlantic to serve the interests of European imperial power. Llegba, of the Yoruban pantheon re-established in parts of the Caribbean region, stands at the crossroads, a space that is ominous yet auspicious. Serge Bramley explains that it is not unusual to see Macumba shrines erected at city intersections in metropolitan Brazil. ${ }^{1}$ They are symbols that Caribbean peoples are always at the crossroads where various cultural influences intersect, in the continuous process of becoming, or as V.S. Naipaul would say, there is always an arrival at another (material, psychological, spiritual, and social) location, and therefore into another state of being. ${ }^{2}$ The bridge is swinging, and arrivals and departures are taking place.

The metaphor of swinging bridge, applicable to the Caribbean 
as a region, includes legal and illegal crossings. Many crossings follow the route and inclinations of the triangular trade of the nineteenth century. In today's world, narco-trafficking is perhaps the most profitable (to some), and destructive (to others), trade in the region. The Caribbean is the "third border" (another metaphor) to both North and South America, the former biggest consumer of narcotics, the latter the biggest supplier. Helicopter "drops" are made in the aquamarine waters that adorn tourist brochures. "Packages" can be smuggled, side by side with tourists, on luxury yachts or cruise liners. Narco-trafficking and the sex trade go hand in hand. Toute bagai- human trafficking is part of the bagai! ${ }^{3}$ Legal and illegal crossings are made, too, by Caribbeans, migrating to North America for career and education opportunities. Kamau Braithwaite writes

there was so much going on above us $\&$ around us what with the ferrymen shouting and fighting for survivors though we were all quite dead \& bloated

by this time

\& some of us had even started floating on our blacks up to the surface which is when I suppose we cd barely see

that nobody wasn't throwing no lifelines nor booies nor anything like that towards us (1998: 109)

His images, painfully extracted from the slave trade, speak of the contemporary situation as well. The reference to "the ferrymen" brings in the element of a voyage across time and ever-looming danger of crossing into death. These crossings are also navigations of identity-willingly, in desperation, or through coercion. The traveler embarks with one identity, disembarks with another, yet $\mathrm{s} /$ he carries the former into the latter environment. Ramabai Espinet's novel, The Swinging Bridge draws metaphors from this reality of crossings in order to explore identity for people of Indian ancestry who crossed to the Caribbean within the historical frame of nineteenth century indentureship. ${ }^{4}$

With the emancipation of slaves, indentured immigrants from colonial India were Britain's solution to the need for plantation labor. So thousands of Indians-coerced, manipulated, or self- 


\section{Ethnic Studies Review Volume 31}

determined-set off in the holds of ships, bound for "Chinidad," (and other Caribbean territories) ${ }^{5}$ the land of sugar, ${ }^{6}$ with little awareness of their place vis-à-vis the ex-slave population in the colonial history of the region. Relations between the new arrivals and the existing Afro Trinidadian population were not cordial for Afro Trinidadians saw the new workers as strike breakers whose labor would undermine their own attempts to secure livable wages. The colonial policy of "divide and rule" maintained hostilities, the negotiations of which continue to be central to power sharing as well as to identity articulations in Trinidad.

For Indians, interminable months on the kala pani had brought them to interminable years on the plantations during which the struggle of the laborers for physical survival was simultaneous with their attempts to define and articulate themselves in the new environment. Here we have the earliest metaphor of Indo Caribbean identity — kala pani-which literally translates as "black waters," as the immigrants referred to the oceans they crossed for the first time. According to the Hindu system, to cross the ocean would be to lose caste and therefore one's place in the social and religious order. For those of lower castes, this loss would be liberating, for those of higher castes, it would be grievous. In any case, the venture was one of uprootment and the crossing was fraught with physical dangers, with a deep sense of the unknown, but also with the anticipation of starting a new life. The combination of loss, fear, confusion and courage has been expressed metaphorically as kala pani. This metaphor has been used to make a comparison between the historical crossing and the discursive crossing of boundaries that occur in writing. In her exploration of the writing of Indo Caribbean women, Brinda Mehta describes the metaphor of the kala pani as "a discourse of rupture that initiates transgressive boundary crossings through (self-) assertions in literary production" (4). Espinet is one of these writers whose work transgresses the boundaries of what is expected of Indo Caribbean women. She develops female protagonists who embody the spirit of adventure and self-will that motivated the original women who crossed the kala pani. Swinging Bridge invokes the first swinging bridge:

The year is 1879, and the women have been brought by train 
form Benares to the port city of Calcutta. Small boats ferry them to a ship, The Artist, anchored in the mighty Hoogly River. The gangplank clacks and swings precariously as the women scramble up on the deck. (3)

And so begins a novel whose theme and structure is crossings via swinging bridges. Through the reflections of its protagonist Mona, an Indo Trinidadian woman who has migrated to Canada, this novel assembles the history of a family and a people for whom journeying defines their identity. Mona's family, after a few generations in Trinidad, left around the time of flag independence in the early 1960s, and when we meet them Canada some forty or so years later, the family is gathered around Mona's older brother, Kello, who is dying of AIDs. It is his wish that Mona go to Trinidad to recover family land that has been lost during hard times. As she contemplates the journey back to Trinidad, floods of memories surface and, on arrival, she combines the property business with an excavation of the family's history. Mona is helped by her cousin Bess who is simultaneously working within a committee to establish a museum to record and celebrate the survival strategies of the early Indian immigrants. Through Mona's analysis of her family's life, we follow the development of Indo Trinidadian identity.

It is useful to frame Indo Trinidadians exploration of identity within Caribbean's articulation of its regional culture. The earliest metaphor of Caribbean culture is creolization. Historically, the term "creole" originated within the plantation structure where Europeans used the word creole to mean island-born-people, animals, and plants - as opposed to European-born. The word was coined to express the irreversible adaptations to geography and social circumstances. Implicit, too, was the hardiness and beauty of a creole entity. The contemporary use of the word creole originates in Kamau Braithwaite's (1971) definition of creole as the interculturation of African and European elements to make up Caribbean culture. He explains creole as the development a hybridized culture out of the brutal uprootment, and compulsory relocation and re-indigenization of African people as they reinvent(ed) all aspects of culture in their on-going resistance and struggle for liberation at all levels. Creole can be applied aspects of 


\section{Ethnic Studies Review Volume 31}

culture such as language, religion, family structures, music, food, fashion, etc. Creole is grassroots impelled in its creativity and not always accessible to those outside the culture; it evolves out of the instincts and struggle for freedom in all aspects of life; it is ever changing and ever dynamic in unpredictable patterns.

The limitations of Braithwaite's use of the term creole, however, when applied to the Caribbean region as a whole, is that it understates the indigenous inhabitants of the region-the thousands who were massacred but of whom there are resonances throughout the region, as well as the descendants who live in tribal communities or among the mainstream populations; and excludes groups who came under indentureship contracts from China and India. Absent, too, are the groups from various parts of the Middle East who have contributed to the Caribbean's cultural tapestry. For groups who migrated from China, India and the Middle East, severing from the ancestral culture was not as brutal as African slavery, thus the process of re-indigenization has been different from that of Afro Caribbeans. For Indo Trinidadians (and people of Indian ancestry in other parts of the Caribbean), the challenge has been to reconcile the Indian ancestry with its Caribbean present and future, and to carve out a space for itself in a part of the world where it is a minority-demographically and culturally.

While hostilities among Afro and Indo Trinidadian groups simmered at the grassroots level since the arrival of Indians on the shores of the island, these matters were first articulated in public in the late 50 s and early 60 s, at the national level, during the build-up to independence. Afro Trinidadian leadership severely chastised and, according to some perspectives, punished Indo Trinidadians for not completely turning their backs on the Indian ancestry. Indo Trinidadians were called "a recalcitrant and hostile minority masquerading as an Indian nation" by Eric Williams, political leader, in 1958, as he condemned Indo Trinidadians' refusal to accept his leadership and assimilate whole-heartedly into the Afrocreole mainstream according to its rhythm and pace. The threat of engulfment for this group has been a combination of the colonial forces of westernization and the African Caribbean majority presence throughout the region. Swinging Bridge describes how 
one particular family negotiates identity in this context, developing "swinging bridges" of connections with the present cultural and political streams as well as with the Indian past.

In Section One of the novel, "Borrowed Time," Mona goes back into the history of the family, focusing a great deal of Da$\mathrm{Da}$, her father, as an Indo Trinidadian man for whom the attempts to creolize brought much frustration. Creolization meant adapting to the mainstream in everyday activities such as language, dress and cuisine, as well as making one's way out of the rural villages that grew up around the plantations into the urban mainstream for education and socio-economic mobility. To make this latter move, Da-Da mortgaged family land although land ownership was/ is deeply embedded in the consciousness of Indo Trinidadians. Indians initially agreed to contracts that promised return to India after 3 or 5 years but, more often than not, return passage did not materialize and some Indians accepted land in exchange for passage back to India. Others squeezed pennies out of their meager earnings to buy land. Often the land they got in Trinidad was land that no-one wanted-swamp land that sank underfoot, land that was infested with mosquitoes, fleas, and chiggers, land that carried malaria, typhoid, diarrhea, hookworm, and a host of other diseases. But they cleared and drained the land and lepayed the huts that they built, ${ }^{7}$ even as they cried out to colonial governments for electricity, potable water and infrastructure. Indians an Indo Trinidadians at this time were agricultural people, grounded in earth-based practices that evolved in Hindu religion. Also, from the depths of semi-servitude, Indians placed their hopes in property ownership to be used for building home and family, as collateral to obtain investment loans for business and education, or for retirement income. Pappy's (Mona's grandfather) generation, emerging from indentureship, focused on grounding the family in the new land; Da-Da, of the next generation, thrust himself into the mainstream where creole legal and commercial transactions had to be negotiated. Says Mona, "Da-Da was a modern man, sure he could not have been easily fooled, and that the decision to sell and move to the city was a sound one" (58). Betterment of his family was Da-Da's priority, but, exploited, tricked, ridiculed, and finally 


\section{Ethnic Studies Review Volume 31}

bankrupt in the hands of moneylenders, it is up to his own father, Pappy, to start again with a donkey and cart. As Swinging Bridge points out, Whites and near-Whites got credit from the commercial banks, Blacks from their lodges, and Indians had no choice but to accept the impossible terms of money lenders. Mona, coping with her own problems in Canada, recognizes "the wiliness that early Indians like our own grandparents, ignorant in the ways of the creole culture, needed to work out a means of survival in the face of so much hostility" (59).

Through her grandparents' and parents' lives, Mona sees that not only did Indo Trinidadians struggle against the poverty of the plantation and post plantation life; they were also stigmatized for having that life. The psychological and material legacy of colonization defined the clean, good life as far away from the plantation, lodged in the colonial ideal of socio-economic mobility that went hand in hand with the adoption of Europeanized practices. Plantation life was the shame of the region and those who were trapped there were stigmatized. Black consciousness gave another twist to this type of thinking in countries like Trinidad and Guyana (and to some extent Suriname) where black consciousness, ironically, took the form of hostility against people of Indian descent. V.S. Naipaul explores this trend in his novel $A$ Way in the World that shows a pre-independence political meeting in Woodford Square, Port-ofSpain, where open articulation of the pain of Black history becomes ritualized into a movement where Whites may feel excluded but not threatened because "much of the hostile feeling released by the sacrament of the square would have focused on the Indians" (1994: 35). Indo Trinidadians became the target of Black rage even though, as Naipaul shows, there were, at the time, many destitute Indo Trinidadians roaming the streets of Port-of-Spain, some making the city square their home; as well as high levels of poverty and malnutrition in the neglected rural Indo communities.

Nor did Indo Trinidadians see poverty and depression of large numbers of Afro Trinidadians as their concern. The legacy of joint colonial oppression was not a unifying factor and any notion that similar oppression brings groups together can be dispelled. Instead, as Kelvin Singh says in his analysis of later nineteenth and early 
twentieth century Trinidad,

The mutual apprehensions of the African, Indian and Colored components of the colony's middle class, reinforced by the limited upward social mobility achieved by the more ambitious and fortunate elements of that class, militated against any sense of compulsion to transcend racial or ethnic boundaries to achieve common goals. (224)

Class mobility was a driving force that demanded competition, not collaboration, with one's "Others." It must be kept in mind that for many class mobility meant achieving more than handto-mouth existence and clinging to family and community was necessary for survival. The democratic process in this history of racialization threw up political parties along ethnic lines and every family was caught in the schisms that split the population asunder. Mona describes the "outrage and sense of despair" in the letters that Da-Da wrote to the daily newspapers to protest the "partisan display of power for the benefit of the black population" (72). DaDa appealed to the country not to participate in the politics of Afro Trinidadian supremacy being constructed by "De Doctah" - so called to reflect the deep admiration and loyalty bestowed him by much of the Afro Trinidadian sector of the population. Says Mona, "In Da-Da's letters I read the map of our departure from that early island home into a Canadian migrant existence" (72).

Migration to Europe or North America has always been a "swinging bridge" for people of the Caribbean as they widened their personal space. Colonialist Presbyterianism was the raft on which Mona's family left for Canada. The majority of Indians who came from India were Hindus, with a lesser number of Muslims and a few Christians. Mona's family was of Hindu stock and converted to Canadian Presbyterianism in order to get admission in Presbyterian run primary schools. Canadian missionaries targeted Indo Trinidadian communities, offering education in exchange for Christian souls. Religious and secular education was the way out of the cane-fields and cocoa or citrus plantations. Christianity, westernization and social mobility all came together and the family felt aligned to Canada long after they (or at least Da-Da as head of the family) had given up on finding comfort in the Christian God. 


\section{Ethnic Studies Review Volume 31}

Indo Trinidadian families who wanted to maintain Hinduderived practices attempted to syncretise both traditions, but gradually Hindu rituals within the home dwindled, and there developed a distinction between Hindu and Indian. Similar trends were taking place within Muslim families. The slippery category of creolized Christian Indian evolved. Says Mona, "newly educated people would throw out everything Indian at first, and would slowly gather back into their live only those relics that were essential for survival...all seeping gradually back into Indian lives in the towns and all well hidden except at home" ( 29). I use the term "slippery" because, as Swinging Bridge shows, creolizing Indo Trinidadians had to be always on guard lest they "slip" and reveal their rural Hindu roots since colonialist attitudes and procedures made Hindu culture an impediment in the road to "progress." Creolizing Indians suffered the contradictions of rejecting aspects of the ancestral culture that were their sources of survival and the wellsprings of their creativity.

Also, Hindus (and Muslims) met with obstacles at the level of state governance. For example, there were many instances of Indian land being confiscated by the state because, until 1946, Hindu and Muslim marriages were illegal and "bastard" children could not inherit property from their parents. The state seized and redistributed much hard-earned lands. Thus, even sex between non-Christians was illegal. ${ }^{8}$ It follows that cultural taboos that censored sexual behavior also reflected colonial attitudes. Not quite understanding how history bears down on them in complex layers, Mona and her girlfriends are confused about the rules regarding courtship and sex. Section Two, "Manahambre Road," explores Mona and her adolescent friends' attempts to understand how to shape their lives; sexual matters were, expectedly, important. On the one hand, their Indian/Hindu background, with its tradition of arranged marriages, insisted on no contact with the opposite sex. On the other hand, the practice of marriage at a young age, also typical of Hindu/Indian families, gave rise to the stereotype in mainstream Trinidad that Indian girls were sexually precocious. Hanging over Indo Trinidadian female sexuality was also the notion that female sexuality had free rein during indentureship when the male-female 
ratio was at times 8-1 and women had some measure of freedom in their choice of sexual partners. Rather that seeing this pattern as sexual liberation, it was chastised by Christianity as sinful. Swinging Bridge describes that in the "slow, deadly respectability" ( 29) of Presbyterianism, Indo Trinidadian parents were overly strict, which in turn was ridiculed by non-Indians as backward, since it was seen as grounded in Hindu practices of gender separation. Mona recounts,

Susie's [her school friend] family was as rigid as mine about allowing her to go to parties and public fetes. Most of my Indian friends had the same problem, but we suffered in silence. It was yet another shameful Indian secret to be kept from our creole friends and those of other races who would hold us up to ridicule for being backward. (186)

Western style romances offered escape fantasies for the girls who were surrounded by wifehood drudgery, incestuous abuse, or suicide among their peers. Yet these fantasies also brought culturally loaded recriminations. When, as school girls, Mona and her friends are caught with romance novels, they are accused of being historically over-sexed. The tendency to promiscuity was seen as a by-product of the plantation life, to be erased by Presbyterian religion and education. Miss Camilla Lee, a Presbyterian teacher, reprimands, "I say all-yuh leave that kinda ting behind on the estate long time! Why all-yuh so hot up?" (144) And Lee makes the connection between sex with low-income Indo Trinidadian men and curtailment of opportunities for advancement when she says, "What these little taxi-driving boys could give you all in life?" (144) For Mona and her friends, the penalty was ultimate if they stepped out of the narrow confines set for them; education was the needle's eye through which they could pass to escape a life of drudgery and misery, and, along with academic achievement, this education included colonial Presbyterian-defined definitions of appropriate sexual behavior. Says Mona, "One false move could cost everything - my whole life" (139). As becomes apparent when a lovelorn friend commits suicide, to expect the romance of comic books was a false move.

In fact, in transitioning from Hindu gender arrangements 


\section{Ethnic Studies Review Volume 31}

to creolized structures of more casual intermingling, there was no clear definition of what was not a false move. Inter-racial relationships were a sore point. Indo Trinidadian parents were wary that mainstreaming put their daughters at risk for getting sexually involved with Afro Trinidadian males and, given the context of racial Othering, this was a serious betrayal. Mona feels the wrath of her father's anxiety when, as a teenage girl, her shift dress catches the eyes of males. Mona's father reprimands, and later tears the offending dress and makes her kneel in the yard. Mona is of course bewildered, but later reflects that all her father's objections were about the possibility of Bree, the Afro Trinidadian male who is her first love. Sex was not just sex, it was the core of ethnic identity and as Patricia Mohammed explains, there was a stronger historical pattern of Indo Trinidadian women, vis-à-vis their male counterparts, marrying out of their ethnic group (194-95). The Indo Trinidadian community was watchful that schooling put its daughters in spaces where they would spurn the very same "backwardness" from which education would liberate them. Creolization carried the risk of evaluating everything that was Indian as backward. Noncreolized Indo Trinidadian males were part of this backwardness; immodest dress the first symptom that an Indo Trinidadian woman had internalized the notion that Indian traditions and people were backward. Mona first comes into contact with those sentiments when a taxi driver "drops" words for her:

Indian boy go ketch hell jes now. Nowadays all de girls going in for Creole boy. Watch them nuh, in dey tight skirt and tight pants, looking for Creole boy. Indian boy eh good enough for them, Indian boy go see trouble jes now, yuh go see. (172)

Creole here would mean any ethnicity that included African. Anxiety about masculinity can also be framed within the construction of masculinity in the Caribbean context of colonial hierarchical multiculturalism. For white Trinidadians, male confidence was located in western hegemony. Afro Trinidadian men were seen as physically strong, athletic, aggressive, and therefore having sexual prowess. Indo Trinidadian men were considered as physically weak, family-bound, un-aggressive and rural; all these traits added up to sexual inferiority. Swinging Bridge illustrates this disdain for Indo 


\section{Kanhai-Fire in de Cane}

Trinidadian male sexuality during a Carnival (mardi gras) season when Da-Da is accosted thus,

The woman was middle-aged, voluptuous, dressed in tight pants and a short jersey top. She sang before Da-Da in a trance, her closed fists positioned at crotch level, both thumbs making scooping movements, while he stared straight ahead, not a flicker crossing his face. (101)

The woman would be Afro Trinidadian. She mocks Da-Da's sexual (im)potency in a symbolic rape and Da-Da, with no way of responding to this public humiliation, stands paralyzed, even more convinced that "It have no place here for Indians. I have to get out of here. By hook or crook I go get out, yuh hear mih?" (101) At the national level also, Indo Trinidadian men were discursively emasculated since the media, cultural mainstream, and the governance structures were, after the colonial period, increasingly Afro Trinidadian dominated, with lingering respect for Whites or near-Whites. Bree-the young, urban, creole athleteis bursting with sexual confidence that is gifted to him in a process that has belittled Da-Da. That Bree's self-identity is grounded in the ascendancy of Afro Trinidadian politics is revealed when Mona and her friends question Bree on his total loyalty to Afro Trinidadian leader, the Doctah. Bree's response is to repeatedly slap Mona, precipitating an end to their relationship. Years later, when, in New York, Bree casually announces that he is safe on the subway because he is Black, Mona reflects, "His words, casual, unthinking, disturbed me. He was black, yes, and I was not. Would I be safe on the subway too?" (188). In fact, she reflects, even if she could be seen as black in New York, there was no room for that type of thinking in Trinidad.

Can a swinging bridge be constructed to cross the gap between Mona and Bree?

Some Indo Trinidadian theorists have utilized the term "dougla" as a metaphor of the interculturation of African and Indian based cultures in Trinidad at the grassroots level. The word dougla is derived from the Bhojpuri word for bastard or illegitimate. ${ }^{9}$ It has been used in Trinidad and Guyana to refer to a person of mixed African and Indian ancestry. Shalini Puri coined the term "dougla poetics" 


\section{Ethnic Studies Review Volume 31}

as a means for articulating potentially progressive cultural identities de-legitimized by both the dominant culture and the Mother Culture...the figure of the dougla draws attention to the reality of interracial contact; it names a contact that already exists. Second, the dougla could provide a rich symbolic resource for interracial unity. (1999:273)

Puri's dougla poetics is a counter to ethnic purity as well as to Braithwaite's valorization of creole culture as developing from the interculturation of African and European elements. The term dougla articulates the reality of post-independence in Trinidad and Guyana where identity is being molded within the turbulent confluence, of the Ganges and the Nile, ${ }^{10}$ to refer to another metaphor. I personally used the term "dougla feminism" in a lecture at UWI Center for Gender \& Development to critique the Afro domination in Caribbean feminism and to make a case for a Caribbean feminist movement that could draw on and be enriched by the experiences of the Indian populations in the region.

However the calls to ethnic nationalism are rooted as they are in the struggle for power in a history of ethnic division. Independence in the 1960s marked a culminating point in this history. Ushered in by an Afro Trinidadian dominated political party, independence was clearly an anti-colonial triumph for the Afro Trinidadian population who set the pace and tone, despite the protests by Indo Trinidadian leaders that their people were being left in the cane-fields, literally and figuratively. The "face of the nation" was metaphorically and literally black male. The case was made that it was time for white men to hand over leadership to black men. Black women were expected to give support and brown men and women were pushed to the margins in that almost-sacred transition. Yet, the invocation of national unity and historical pride compelled the recognition that those in the cane-fields were Indo Trinidadians, and there were token attempts to exoticize cane-field life at the cultural events organized to celebrate independence. Mona recalls La Rosette, a dancer and choreographer from the city, training Indo Trinidadian students in the sugar belt to put into dance the motions of cutting cane. She urged them,

"Cut cane! Like this! Now bend, now walk with a bucket of 
water on your head, walk with a bundle on your back, a child, a bag of cocoa, walk with your heads up, proudly, proudly, peasant women, country women, cut cane!" (68)

These students showed little enthusiasm; they could not participate in exoticizing the peasant life. The misery of the cane-fields surrounded these students; they saw parents stretching themselves so that their children could escape the cane-fields. La Rosette's choreography, culled from her training in Western and African forms was creolized, but did not adapt to the reality of Indo Trinidadians in the sugar cane belt. There is no indication that she made efforts to understand this groups thinking or to study their art forms. Creolized city people could come to the sugar belt to "teach" culture but there was no acknowledgment that the city folk could "learn" from for the rural artists. For example, Sundar Popo, a talented Indo Trinidadian chutney singer, ${ }^{11}$ was at the time singing

kaisebani kaisebani ${ }^{12}$

mi Nana and mi Nanee was flying in a plane

the plane catch a fire

they fall inside the cane

Creating an image of Nana and Nanee consumed by the airplane/ cane fire, ${ }^{13}$ Popo echoed the despair that the much celebrated independence was not freeing Indo Trinidadians them from the cane. ${ }^{14}$ Says Sheila Rampersad, "This cry came from a man who had spent his life in the sugar cane belt where the communities were named for the cane scales: Scale \#1, Scale \#2, etc." This metaphor of being trapped in a cane fire powerfully expresses Indo Trinidadians understanding of their desperate lot at this time.

Yet escape by "plane" was possible for some, including Mona's family as they planned and executed a migration to Canada. Significantly, Mona makes a distinction between Trinidad as "island home" and Canada as "migrant existence," for re-indigenization, as it happened in Trinidad, was never attempted in Canada. The migration to Canada is not presented as another step in the journey from India with Trinidad as a stop-over. Swinging Bridge shows that many Indo Trinidadians left because they felt themselves "at a standstill. The bloody racial riots in British Guiana had fuelled their sense of despair about the future" (77). The reference is 


\section{Ethnic Studies Review Volume 31}

to the Forbes Burnham regime of the 1960s and 70s in Guyana which directed an agenda of violence against Indo Guyanese including rape of Indo Guyanese women, street attacks, looting and arson of Indo Guyanese businesses and farms, and seizure of Indo Guyanese homes and properties. These incidents prompted an exodus of Indo Guyanese to North America, Europe and other Caribbean territories. Indo Trinidadians saw the Guyanese situation as their worse nightmare come true, and as the actualization of the threat of aggression that Afro Trinidadians expressed in political speeches and calypso. They saw this aggression as regionally supported since the anti-Indian violence in Guyana raised hardly a murmur from the Afro Caribbean politicians, historians, artists and social commentators in all fields. The silence spoke volumes and it did not take much stretching of the imagination to be nervous that what was happening in Guyana could easily happen in Trinidad. Yet there was much sadness for Mona's family in leaving "the earth where [their] navel string was buried" (77).

But leave they did, heading for Canada where there was a connection through Presbyterianism. In Swinging Bridge, the family enters a milieu of infinite swinging bridges that have brought individuals and groups of various ethnicities to Canada, itself a country with a history of European conquest, followed by AngloCanadian hegemony; and where indigenous peoples and migrant peoples of color, and to some extent francophone Canadians exist in marginalized statuses. We see the adult Mona who is Othered as an Indian in Trinidad but who identifies with the people of color in Canada such as Carene, a Haitian Canadian woman, with whom Mona is working to make a film on the historic lives of Haitians. The bridge that swings both women together is constructed through, one, their shared experiences as people of color in a major Canadian city and two, the feminist awareness that (Caribbean) women are "edited out of history" (11). For Mona it is a feminism that honors the struggles of women who experience multiple layers of oppression based on ethnicity, class, education and immigrant status. As a person of color in Canada, she brings from Trinidad the sensitivity that males who are not of the dominant ethnicity are marginalized. Mona's awareness of white hegemonic global power 
is one of the reasons she cannot bond with the Euro Canadian Roddy who makes little effort to understand the chaos of her life as it relates to the privilege of peace and security he enjoys. Says Mona, "Peace in Europe indeed, Roddy my love, and no peace at all beyond the line" (205). Yet she must explore how this legacy of violence is woven into sexism within oppressed groups even as these groups struggle for self definition and social justice. How does the Indo Trinidadian woman define agency in such a context?

Ramabai Espinet's short story, "Barred," a sort of predecessor to Swinging Bridge, uses the fictional form to work out some possibilities for an Indo Trinidadian woman. As Shalini Puri pointed out, (2004: 205-215) this story culminates in a Indo Trinidadian narrator who, in the depths of poverty establishes a little shop for economic sustenance and opens up to the Afro Trinidadians around her - the "Negro gentleman" who was her first customer and the "Creole woman" who showed how to make sugar-cakes and tamarind balls. The narrator's male partner cooperates when he sees the viability of the enterprise. My own story "Soul Food" (2001: 91-94) explores the potential of the role of an Indo Trinidadian woman shop keeper in a multicultural village. As this story shows, it was a role suited to Indo Trinidadian women with little education but with domestic skills and an ethic of starting from scratch. This "scratch" included the influences of a multi-ethnic community, and the development of a creolization as a way of life evolving out of necessity, commonsense and spontaneous contact with available styles and raw materials. We see a version of this creolization process in the character of Muddie, Mona's mother, who nourishes her family on "Creole pastries" or "stewed beef with heavy dumplings instead of rice, an innovation that everybody liked" (38). Muddie never articulates a theory of creolization; her concern is to hold "together the fragments, creating something out of nothing" (39). Examples of Muddie's simple, yet consistent acts of securing her family through transitions and crises abound. For example, during the rainstorms in Ramgoolie Trace where the family sojourns for a while, it is Muddie who places

...tin cans and buckets underneath all the leaks, after she had shone a candle in every crack and crevice of the house 


\section{Ethnic Studies Review Volume 31}

searching for scorpions and chenilles and had killed all the mosquitoes that had flattened themselves along the wall... (109)

Her inventiveness as she feeds her family and keeps them safe and dry draws on whatever resources she can put her hands on- material and/or cultural. Muddie is also Mona's moral/ social compass. Vividly imprinted in Mona's memory of a time in Trinidad when Muddie defended of Baboonie, an impoverished old woman who lived alone and whosebody became the dumping ground upon which the village men spilled the sewage of their lust. However, Mona also sees Muddie's pain and limitations. The sexual attack on Muddie by Badall (a male relative), and the secrecy that protects him, show Mona the danger that Indian women meet within the family and ethnic group to which they are expected to pledge loyalty. As in "Barred," Swinging Bridge also shows that there is danger inside and danger outside for the Indo Trinidadian woman. All this is the consciousness that Mona takes with her to Canada but her unanswered questions propel her to take the swinging bridge back to Trinidad.

Mona's return takes place in Part Three of the novel, called "Caroni Dub" - a metaphoric term that brings together two disjunctive sites - the former a geographic location, the latter Jamaican musical form. Caroni is historically and mythically the genesis of the Indo Trinidadian people, the sugar belt that pulled them across the kala pani and curled around them, fastening them in a tight embrace of love and hate, hope and despair. Caroni, its name derived from the main river that irrigates the plains of Central Trinidad, is also the liminal space between country and town, creole and coolie. ${ }^{15}$ This is where Espinet anchors the swinging bridge to reconnect her family from Canada. Mona's family is from South Trinidad and her decision to place her linchpin in Central is explained in her dream:

I am driving on the well-cut new highway that joins the two cities of my life, Port of Spain and San Fernando. I apprehend a newly prescribed order. Here on this highway where the urban North meets the rural South. The bridge across the Caroni River is splendid and wide; small boats are anchored at the 
edge where the river road at the mouth of the swamp leads to a bird sanctuary for scarlet ibises and white egrets. (264) Via this highway-come-swinging bridge, rural meets urban, and the ugliness of plantation history gives way to the beauty of the swamp birds. The splendor of the ripening cane, "their silver arrows shooting into the sky," is the magic reality of the Indo Trinidadian inheritance-sordid in its history yet transcendent in its natural beauty. The dreamer's persona is the mongrel dog that runs alongside the highway, "her dugs loose and flapping, tongue hanging and dry." Traversing a landscape that is fraught with conflict, this dog is in panic, caught as she is "in that dread game called life" (264). But play the game Indo Trinidadians must, as they cross back and forth on the swinging bridge. The rhythm of this game is "Caroni Dub."

Dub is a musical form that evolved in Jamaica in the late 1970s in communities where incomes are the lowest and political clout the leanest. Dub basically remixes existing pieces of music and/ or adds sound effects to what is already there. It was prompted by the Dancehall culture in urban Jamaica where huge sound systems were placed in open air venues and Deejays had to be creative in the use of a limited number of recordings. Deejays compete with each other to come up with an infinite number of variations of the original recording or to layer various recordings into one rendition. Every rendition is a remix but yet is an original, evolving out of factors such as the mood of the crowd, the profile of the Deejay, the range of instruments available and the social circumstances at the time. External sounds can be included such as the noise of passing vehicles, barking dogs or slamming doors. In other words, the 'soul' of the community finds expression.

Swinging Bridge coins the term Caroni Dub to articulate the rhythm of Indo Trinidadians, culled from infinite remixes of the influences of India, the Caribbean and North America. In this novel, the original artist of Caroni Dub is the rand-the widowed or otherwise single Hindu woman in nineteenth century India who, outcast by her family, was compelled to sing and perform in order to earn a living. Spurned and ostracized as prostitutes, perhaps sexually abused, many of these women either chose or 


\section{Ethnic Studies Review Volume 31}

were manipulated into indentured migration. They formed bands to comfort and protect each other on the way and when they arrived in the Caribbean. Says Swinging Bridge "The records of indentureship to the Caribbean show that Brahmin ${ }^{16}$ widows formed an inordinate number of females who migrated" (3). These women carried with them religious, epic and love songs and rituals that registered the creative consciousness of their ancestral communities. Relocated in Trinidad, they were the purveyors of culture and religion that (in) formed the cultural bedrock of Indo Trinidadian communities as they shaped themselves. These women (and some men) were the griots of the community yet they did not get the respect traditionally accorded to griots in many cultures.

Espinet's valorization of the rand is not nostalgia for India but a recognition that Indian ancestry, carried in the hearts and minds of those who migrated, gave the indentureds grounding to build a culture that adapted to the new conditions. Says Mona, "I never wanted to go to India, a place where our ancestors had left more than a century ago" (40). Mona's interest is in the Indians in the Caribbean, not in India. She is thrilled to excavate information on Gainder, her ancestor, a talented woman who, while indentured, sought passes from the colonial overseers to sing and perform on weekends at weddings and other special celebrations, thereby earning extra money. Undoubtedly, many Indo Trinidadian families got a much needed economic supplement from such earnings.

The Ramayana, perhaps the best known Hindu epic, has been sung, recited, performed, put into puppet shows and taken on a myriad of manifestations in India and wherever Hindus have migrated. Unlike other holy texts such as the Koran, the Ramayana lends itself to reinterpretation for any and every occasion. The early dubbing of the Ramayana in the Caribbean were remixes that expressed the mood of the indentured and post indentured community at its lowest ebb. Mona feminizes this despair and degradation in the figure of Baboonie, the "old beggar woman" who is repeatedly raped by the village men and spurned by all. In Canada, during a storm of freezing rain, ice pellets and wind howling through pine trees, Mona's memory throws up the sound of "rainwater pouring down the galvanized spouting of the house 
into the drain at the side" (108) and through that layer of sound, the voice of Baboonie insinuates itself. The voices of Mona's parents arguing about Baboonie is another layer of sound, and then, more ominously, Mona hears "silent figures stalking through the night intent on one thing...Baboonie huddled in a corner, waiting for her assailants, cursing to protect herself. Baboonie subjected to the inevitable, a grunting, groaning man, a whole procession of them" (111). Raped by the community men, Baboonie appropriates the community's most religious text to give her testimony. Her curses, intermingled with verses from the Ramayana, become her "holy" song. She sings, joining the chorus of the "rise and fall of women singing Ramayana at kathas" (112). And her words resonate with Mona thus,

The words were in Hindi and I knew only a few of them dhuniya, popo, beti, kala pani. And there were others that I heard night after night and will never forget, their harshness ripping through earth and water and tearing up the air around me so that even breathing became fearful - kangaal, parisahan, triskaar, thokna, parishan, parishan, parishan, parishan, ...pani, pani. The voice rose and fell in harmony with the rain and river and wetness, pani, pani, pani... (112-113)

Etched in the memory of anyone who has lived in Central and South Trinidad are the sounds of women's singing reverberating through the nights. The pundit drones and the women respond in songs that go deep into the ancestral memory, regenerating the fragile yet unbreakable swinging bridge between past and present, between spiritual and communal. Open air performances of sections of the Ramayana, read or sung in Hindi, were/are frequent and common-place in Trinidad. Even if fewer and fewer Indo Trinidadians understand the literal meaning of the words, they are repeated by rote and offer comfort at the emotional and spiritual level(s). In fact, as Kirk Meighoo explained, Hindi is a de facto second language in Trinidad, used by a significant proportion of the population, not officially declared as a second language, but alive in spaces such as homes, community gatherings, religious rituals and secularized performances.

The repetition of the word pani, repeated at significant junctures 


\section{Ethnic Studies Review Volume 31}

in this novel, is the base drum upon which Indo Caribbean identity is built. Pani, literally translated as water, has multiple connotations: the relentlessness of pouring rain, the repetitive flooding of homes and fields as the Caroni River breaks its banks, the literal and metaphoric oceans that have been crossed, the tears that are swallowed and eventually burst their dams, streaming down in torrents. We see a people in distress, buffeted this way and that by the natural elements, by history, by violence from outside the home as well as within the home. The affirmation and struggle of survival is articulated by the rand, the woman at the bottom of the heap

crying through the night, crying through the rain, breaking up the classical words of the Ramayana with her own tales of exile and banishment, and in broken chords and unexpected riffs telling the story of a race. Of racial and tribal grief, of banishment, of test of purity. (113)

The phrase "test of purity" screams of the misogyny embedded in Hindu history and philosophy. The central conflict of the Ramayana revolves around Sita, the stolen wife of the epic hero, Rama, who must prove her purity. She has been in the company of Ravana, the embodiment of evil, and surely Ravana would have tried to seduce or rape her. Sita undergoes the ultimate test of walking through fire and emerges unscathed. Espinet's novel suggests that Indo Trinidadians look, not to Sita, the exalted queen, but to Baboonie, the old beggar woman as the illustration of female heroism. Baboonie's victimization and deprivation is the match to Sita's purity. Baboonie re-mixes the text of Ramayana so that it becomes her own "holy" story; thus redefining the meaning of "holy." This recognition of articulation through suffering is Mona inspiration as she collaborates with her cousin, Bess, to research and document the history of Indians in Trinidad.

From Bess Mona hears the history of the family as one of cultural and ethnic cross-overs even as individuals showed respect for ethnic ancestry. She traces the ancestral Grandma Lil's love affair with a man of Euro Indian ancestry, himself the product of the plantation practice of white massa rape of indentured (or slave) woman. Yet it was the woman's responsibility to bestow respectability to the 
community through sexual virtue. Even when the twelve year old Mona is almost raped, her mother blames her lack of judgment for finding herself in a position where rape could take place. From the Indian widow/prostitute, to indentured woman raped in the fields, to Baboonie raped by the village men, to sexual attacks within the family, the novel traces a lineage of women struggling against sexual abuse to knit together family and community. The threads used in the knitting were their suffering, their hope, their resistance and their determination to forge a structure to protect each other. This structure can be seen as creolized since it draws on the various influences available. Creolization here is more than a cultural identity or a power-sharing strategy, it is an ethic that Mona learns from her female lineage and that she carries back and forth on the swinging bridges that she traverses. Speaking of the ongoing process to develop a system of ethics in the Caribbean, Lloyd Best explains how the ethical void of Caribbean history compelled its people to draw on cultural and religious affiliations for a vision of integration,

The policy of shipping people in merely to work and provide labor power was, oddly, haphazard and bereft of any effective ethos of integration until the cultural and religious resurgences that we have been groping towards since independence.

Best suggests that an ethic of integration is necessary in the Caribbean and this ethic is to be is culled from disparate ancestries, so shadowed in misery and demoralization, through cultural and religious resurgences. Mona's return to Trinidad is framed within a time of resurgence for Hindu/Indians. As young girls Mona and her girlfriends resisted being "civilized" in games such as the Dirty Skirts Club where they secretly refused to wash their uniform skirts because of all that this uniform symbolized about the superiority of colonial Presbyterianism. The adult Mona realizes that generations before there were relatives who rebelled against the "prissiness of the Indian Presbyterian life with its hundreds of restrictions handed down by foreign missionaries" (287). As Brinda Mehta points out,

Colonial school offer[ed] a ... pathology of confinement evidenced in the commodification and subsequent devalorizing of Indian-Caribbean culture and the incompatibility of colonial 


\section{Ethnic Studies Review Volume 31}

education with ethnic traditions. (42)

However, Mona utilizes the same colonial education to liberate herself from its very clutches and by the time she returns to Trinidad, no longer does she feel shame about what is Indian and Hindu derived. She joins the wave of open celebration of the survival skills of the ancestors. Another swinging bridge must be constructedthis one to honor those made the first crossing. Mona takes it upon herself to assemble a family album, filling in the missing pages that were torn out either out of shame or disapproval. She excavates and translates the songs of Gainder, her rand ancestor who was forbidden to sing and dance by her Presbyterian preacher husband. "These songs were my bounty," says Mona, "swinging open a doorway to another world, returning across the kala pani to the India the girl Gainder had left" (293). She plans a film of Gainder's life.

Her cousin Bess is constructing a swinging bridge at the community level. She is working with a committee to establish a museum of Indo Trinidadian history, and while there is the inevitable squabbling, sexism, and other types of power play, Bess realizes that all are motivated by the pain of their shared history of marginalization and their determination to be self-defined. Indo Trinidadians have wrested the "right" to Trinidadian identity, and have reached a place of assimilation at their own pace. Says Bess, "You know how people talk about Trinidadian culture and another culture called Indian culture? So Trinidadian culture don't have place for Indians too?"(285) She rails against and simultaneously sympathizes with Presbyterian families like her own who internalized hatred of their ancestral background, "They hate the history that marks them as coolies." Continues Bess, "And why? Coolie people wasn't people too?" At last, coolie has been reclaimed! And Bess does it in grand style, marking Divali celebrations ${ }^{17}$ in a public bazaar with pillars of lights within which are displayed artifacts of the early life of the immigrants such as the cooking styles and implements, songs mounted on creatively designed panels, and the intricate jewelry of Indian artists. It is fitting that the Divali, the festival of lights, is swinging bridge through which the public is invited to make this crossing in triumph and jubilation-not only because it is the symbolic triumph of "light" over "darkness," but 
because the celebration of Divali was a symbolic cultural/religious triumph against the forces of Christianization in the early days. From the onset, Divali was celebrated by Hindu villagers who made their own clay pots to be lit with cotton wicks soaked in coconut oil that they skimmed in their kitchens. Another cultural triumph was the declaration of Divali as a national holiday in Trinidad (and Guyana) where public religious festivals were historically Afro Christian. As the Hindu community has prospered, its prosperity was/is reflected in the increasing grandeur of Divali celebrations.

How does such "cultural triumph" contribute to understanding Caribbean identity as it continues to weave itself? One answer comes from Viranjini Munasinghe who concludes in her anthropological study of an Indo Trinidadian community,

If indeed Indian-Trinidadians have managed to realize their vision of a plural nation composed of many ethnicities, or possibly even begun establishing their own hegemony, then the rules of the game for claiming native status may have changed and the symbolic privilege of Creole may no longer carry the same valence. (282)

While I agree that Indo Trinidadians have dismantled the notion creole as the privileged status in the Caribbean, there is no indication of an Indo Trinidadian hegemony. The group's ineffectiveness as a political force in Trinidad makes hegemony an unlikely scenario. In any case this novel does not advocate hegemony, it takes us to the poetic space of the swinging bridge which, by its very structure, is not conducive to hegemony.

A swinging bridge is a terrifying yet exhilarating experience, undertaken under extreme circumstances, and with a mixture of desperation, excitement, hope, and anxiety of the unknown. The travelers or "jahajis"18 might be coerced, or conditions on their side of the bridge may be so extreme that they undertake the crossing in spite of their anxiety. Implicitly, there are two locations and a man-made construction that connects both. The bridge is held up by such transparent filaments, "web-like" according to Espinet's novel, that the fear of plunging into the abyss is always imminent. Underneath is the void-the bottomless pit. Who knows what lives in those unfathomable depths? The wind may swing the bridge in 


\section{Ethnic Studies Review Volume 31}

unexpected directions, or someone can stand on firm ground and rock the bridge while the crossing is in process. The walkway of the bridge is made of thin slats of board, strung together with rope. Any knot in the rope can fray, any slat can be rotten. A slat may crumble underfoot. The traveler stops, paralyzed, unable to move forward or backward, yet, move s/he must, for the wind is blowing harder and colder, night is approaching, and voices are calling out from either end. The bridge is narrow and can only hold so many; sometimes it gets crowded and there is the chaos of simultaneous pushing and pulling. Did the traveler have to stand in line to get on the bridge? Was it a years' long journey on which s/he lost her way several times? What did she take for the journey? What was discarded in order to get access to the bridge? What fell over the side or through the slats in the process of the crossing? Were there robberies or assaults on the bridge? Travelers are hurt and dying before each other's eyes. They tell themselves stories and sing songs for the courage to continue. The journey must be made and each survivor is a celebration.

\section{Notes}

1 Macumba is an Afro Christian religion practiced in Brazil.

2 V.S. Naipaul, in an interview with Hilary Chadwick regarding his book The Enigma of Arrival.

3 A francophone creole term that literally translates as "everything." It suggests a collection of vastly different objects or activities, lumped together so that the expected and legitimate is placed together with the expected and the legitimate.

4 From here on in this paper I will refer to Trinidadians of Indian ancestry as Indo Trinidadians; and use the term Afro Trinidadians to refer to Trinidadians of African ancestry.

5 Large numbers of Indians were brought to Trinidad, Guyana and Suriname, with smaller groups going to Jamaica, Grenada and Belize.

6 This is an ironic quantum leap from the Bhojpuri "Chinidad" meaning "land of sugar" to the name Trinidad, given by Columbus to commemorate the Christian Trinity.

7 Lepay: a practice brought from rural India of daubing earthen walls and floors 
with a muddy mixture of clay and cow dung.

8 African based religions were also illegal.

9 Bhojpuri was the dialect spoken by most indentured immigrants.

10 I am borrowing here from David Rudder's soca-calypso The Ganges Has Met the Nile that affirms Trinidadian identity as evolving from the Ganges (metaphorically India) and the Nile (metaphorically Africa.)

11 Chutney is "hot and spicy" Indo folk singing and performance.

12 Un-translatable chorus used in many chutney songs.

13 Nana $=$ maternal grandfather; Nanee $=$ maternal grandmother. These terms are also used to refer to Indian ancestors, implying respect, love and connection with indentureship.

14 I express thanks to Sheila Rampersad for this analysis in a telephone conversation.

15 Coolie was the derogatory term given to Indian immigrants and their descendants. Derived from the Tamil word "kuli" which means one who carries load, this term has been used by to stigmatize Indians and people of Indian descent long after many left plantation labor to become professionals, entrepreneurs, artists, athletes, etc.

16 Brahmin denoted upper caste, in contradiction to the commonly held opinion that most of the migrants were lower castes.

17 Divali is a Hindu religious festival.

18 Jahaji literally translates from Bhojpuri as traveler. Trini and Guyanese-Indians speak of the jahaji bundles which were brought from India, or the jahaji kin that were formed on board the ships that brought them to the Caribbean. It is a historical term that has become metaphoric, bordering on mythic.

\section{References}

Alexander, Jaqui M. Pedagogies of Crossing: Meditations on Feminism, Sexual Politics, Memory and the Sacred. Durham: Duke University Press, 2005.

Best Lloyd, "Subverting Race Politics." Trinidad Express, July 16, 2006. Internet version. 


\section{Ethnic Studies Review Volume 31}

Braithwaite, Kamau. The Development of Creole Society in Jamaica: 1770-1971. Oxford: Clarendon Press, 1971.

—_. Dreamstories. London: Longman Group, 1998.

Bramley, Serge. Macumba: The Teachings of Marie-Jose, Mother of the Gods. New York: City Light Publisher, 1994.

Chadwick, Hilary. Interview with V.S. Naipaul in Association with R.M. Arts. Princeton: Films for the Humanities \& Sciences, 2003.

Espinet, Ramabai. The Swinging Bridge. Toronto: Harper Perennial Canada, 2003.

--. "Barred." In Carmen C. Estevez \& Lizabeth Paravisini-Gebert, Green Cane, Juicy Flotsam: Short Stories by Caribbean Women. Rutgers University Press, 1991.

Kanhai, Rosanne. "From Matikor to a Dougla Feminism." Lecture given at the Centre for Gender and Development Studies, University of the West Indies, St. Augustine, Trinidad, February 1999.

--. Ed. Matikor: The Politics of Identity for Indo-Caribbean Women. St. Augustine, Trinidad: UWI Continuing Studies Press, 1999.

--. Rage and Renewal. St. Augustine, Trinidad: UWI Continuing Studies Press, 2001.

--. The Green Face Man. St. Augustine, Trinidad: UWI Continuing Studies Press, 2007.

Meighoo, Kurt. "Language and the Afro-Saxon Self Contempt." Trinidad Express, July 27, 2005. Internet version.

Mehta, Brinda. Diasporic (Dis) locations: Indo-Caribbean Women Writers Negotiate the Kala Pani. Mona, Jamaica: University of the West Indies Press, 2004.

Mohammed, Patricia. Gender Negotiations among Indians in 98 
Trinidad, 1917-1947. New York: Palgrave, 2002

Munasinghe, Viranjini. Callaloo or Tossed Salad: East Indians and the Cultural Politics of Identity in Trinidad. Ithaca: Cornell University Press, 2001.

Naipaul, V.S. The Enigma of Arrival. Harmondsworth: Penguin Books, 1987.

—_. A Way in the World. Harmondsworth: Penguin Books, 1995.

Popo, Sundar. "Mih Nana and Mih Nanee" unrecorded.

Puri, Shalini. "Race, Rape and Representation: Indo-Caribbean Women and Cultural Nationalism." In Kanhai, Matikor, 23882.

--. The Caribbean Postcolonial: Social Equality, Post-Nationalism, and Cultural Hybridity. New York: Palgrave Macmillan, 2004.

Rampersad, Sheila. "Phantoms of the Cane." In Kanhai, The Green Face Man, p. 2.

Rudder, David. "The Ganges Has Met the Nile." International Chantuelle. New York: JW Productions, 1999.

Ryan, Selwyn. Race and Nationalism in Trinidad and Tobago. Toronto: University of Toronto Press, 1974.

Singh, Kelvin. Race and Class Struggles in a Colonial State: Trinidad 1917-1945. Mona, Jamaica: University of the West Indies Press, 1994.

Walcott, Derek. Collected Poems 1948-1984. New York: Farrar, Straus \& Giroux, 1984.

Williams, Eric. "The Dangers Facing Trinidad and Tobago and the West Indian Nation." Speech at Woodford Square on April 1, 1958. Documented in Ryan, Race and Nationalism, 192. 